\title{
"Area" Under the Background of Strategic Plan of Xinjiang and Kazakhstan Financial Support Energy Cooperation
}

\author{
LI Cuiping \\ China Academy of Xinjiang University of Finance and Central Asia Economic and Trade (Xinjiang \\ Urumqi 830012) \\ 335300609@qq.com
}

Key words: silk road economic belt; Energy; financial

Abstract: with the development of the global energy financial integration, the international energy market financialization trend increasingly highlighted.As China's energy consumption is rising year by year, external dependency of energy shortage in China's energy security and energy dependence become one of the greatest risks to the future."Silk road economic belt" cooperation framework in the first energy cooperation, as the world's third-largest oil exporter of kazakhstan will be one of China's important energy importers.As a result, the deepening of the silk road economic belt under the background of energy cooperation between China and kazakhstan, financial integration strategy system, to build up the two countries is to ensure that China's energy security, the important measures to achieve sustainable economic development.

\section{The introduction}

All the way around the implementation of the "area" important strategic idea, much starker choices-and graver consequences-in planning outline is put forward in xinjiang, xinjiang and central Asian countries adjacent to the geographical advantages into full play, to speed up the silk road economic belt core area construction in xinjiang.In the construction of core area, is gradually deepening regional economic and trade cooperation between China and kazakhstan, especially the deepening of the energy cooperation between the two countries; The development of energy economy cooperation is a key link in the process of the silk road economic belt industry chain, will promote economic and trade cooperation between the two countries and industry cooperation, promote the optimization of industrial structure, to build a win-win mechanism of the development of regional integration of the two countries, manifests the national strategic significance.In recent years, the rapid development of bilateral energy cooperation between the two countries, the rapid growth of the import and export scale of the areas of cooperation and cooperation channels also gradually widened.The energy cooperation between the two countries including oil and gas exploration and development, pipeline construction, processing, sales, technical cooperation, and energy and financial cooperation, etc.Kazakhstan is emerging economies, on the verge of the Caspian sea energy, is the world's third largest oil exporter, and the world's second largest oil consumer in China have strong complementarity in resource trade.Strengthen bilateral energy cooperation between the two countries, to achieve energy supply and demand docking, realize regional energy industry complement each other, promote the coordinated development of the two economies.But in the process of energy cooperation between the two countries still faces many restrictive factors, underfunded is especially outstanding, which restrict the sustainable development of energy cooperation between the two countries.

With the development of economic globalization, financial attributes of the energy is more and more outstanding, energy finance also gradually segmented from the energy resources, financial 
support, the problem of energy cooperation should be gradually promoted to national strategic height to know.Kazakhstan is the world's third largest oil exporter, and energy trade in oil in dollars and settlement, in order to prevent the dollar exchange rate volatility and global financial bubble effect on the economic benefits of the two countries, the two countries can build oil trading consultation in the field of energy cooperation "the market price and energy development fund", construct the oil financial strategy, the two countries to promote effective link of financial capital and energy industry cooperation, support enterprises to go out, for example, buy overseas resource companies and oil;Building energy reserves and investment Banks, helped push oil currency swaps, oil yuan-denominated settlement to regulate the energy between the two countries in the formation mechanism of financial integration strategy.

Bank deposits now kazakhstan dollarization rate has reached $63 \%$, exchange rate risk is great, for this, the two countries in energy cooperation is necessary for oil trading currency diversification;In petrodollars vulnerability to dollarization, increasingly prominent, and the situation, the diversification of oil price and currency settlement has been the trend of The Times.In 2015, China's demand for crude oil increased about 14 to 170000 barrels a day barrels.In 2011, the two countries signed a $\$ 7$ billion currency swap agreements, and promote the cross-border renminbi settlement, these strategic move to further enhance the core status and advance the renminbi regionalization laid a foundation.

\section{The financial support of status quo analysis of energy cooperation}

(1) high-level dialogue mechanism.In 2011, China's central bank entry into central Asia, the black sea and the Balkans central bank governors meeting organization, further deepen china-kazakhstan bilateral financial cooperation mechanism.Bilateral financial cooperation subcommittee in bilateral local currency settlement and project financing cooperation talks has achieved positive progress; In 2012, the Shanghai cooperation organization and the second meeting of finance ministers and central bank governors, members of the government is planning the sco development bank, the financial and economic cooperation mechanism, local currency settlement and facilitation, and other fields has carried on the thorough discussion.

(2) the deepening financial institutions cooperation.Industrial and commercial bank of China almaty co., LTD was established in 1993, becoming the first Chinese Banks into kazakhstan in our country, the same year kazakhstan in almaty, the bank of China was founded.At the end of 2005, China development bank into central Asia in the first team.2012 xinjiang hualing group successful acquisition of a $90 \%$ stake in the Basis of Georgia bank become to acquire the first Chinese private enterprises of commercial bank, marked the our country the development of private capital in the field of overseas financial major breakthrough.

(3) important platform for the exchange and communication.China expo "urumqi foreign economic relations and trade fair" is the inheritance and sublimation, as a showcase and carry out the central policy in xinjiang support platform and the carrier of further opening to the outside world.The people's bank of China hosted the first China - 2013 expo financial cooperation BBS, from then on, unveiled in xinjiang of China financial west to open a new chapter.

\section{The financial support constraints facing the energy cooperation}

First,Is a bilateral local currency settlement channels is not clear.Ha has not been established in 
cross-border settlement system directly, though, the two sides signed a bilateral local currency settlement agreement, but as a result of both sides to establish agency co., LTD., to a great extent, restricts the yuan's cross-border flow.In the local currency settlement agency agreement signed by both parties is regional Banks, more concentrated in almaty, small and medium-sized cities almost no outlets, and the import and export of energy enterprises in China more concentrated in the border areas such as xinjiang, it is difficult to meet the needs of the enterprise or individual to local currency settlement, so to some extent, restricted the local currency settlement business to carry out the two countries.

Second, it is china-kazakhstan cooperation between Banks a bottleneck.On the one hand, our country bank branch power co., LTD., established in the business development of space, with the continuous development of bilateral energy cooperation, the two countries financial services put forward higher request, for all kinds of local currency financial business, for the connection of financial business and financial institutions set up has become a top priority.Financial support energy cooperation between China and kazakhstan, on the other hand, the lack of corresponding risk management mechanism, the lack of trust between our two Banks, information asymmetry, lack of corresponding bilateral energy cooperation system of financial support.Under the condition of commercial bank risk exists generally in kazakhstan, it is difficult to carry out Chinese commercial Banks, on the energy cooperation of financial services.

\section{Countermeasures and Suggestions}

establish crude oil futures market, avoid the risk of the international oil price fluctuations.China's crude oil imports from hasa Stan volume increased year by year, kazakhstan crude oil exports to China in 2013, 11.85 million tons of xinjiang from China to kazakhstan crude oil pipeline, about $1200 \mathrm{~km}$ long, after put into use in oil and gas pipelines, since 2006, our country through the pipeline, a total of 63.62 million tons of imported crude oil.

\section{Acknowledgments}

(1)China's National Social Science Fund Projects 《Build based on xinjiang radiation asia-europe cross-border cotton futures market research 》(16 BJY171); (2)Xinjiang University of Finance and Economics PhD Student Research Innovation Project 《The "silk road economic belt under the framework of financial support research energy cooperation 》(XJUFE2015K002).

\section{References:}

[1] Mo zhang nan, search the new map of China energy financial strategy [J], the financial expo, 2009, 7

[2] Mo zhang nan, "energy financial integration strategy system is imminent" [J], the economic environment, 2009, 6

[3] Mo zhang nan, the financial system to build up the new [J] "strategy map", "development", 2009,4

[4] wang yu, hand in hand to the future [J], "the western financial", 2013, 9

[5] liu-qin Chen, under the new situation of our country oil financial strategy [J], the power and energy, 2011, 3

[6] ellazhang, ha oil cooperation in 20 years (1993 2013) retrospect and prospect of [D], 
xinjiang normal university, 2014

[7] determine, to promote the development of central Asia, cross-border RMB business thinking [J], the financial economy (theory), 1, 2014

[8] lan-fang cheng, clean pigeon, international crude oil price fluctuations on the analysis of the conductive effect of price [J], issue price, 2013.12

[9] zhi-guo li, Guo Jinggang, international crude oil price fluctuations on China's macroeconomic transmission and influence - the empirical analysis based on SVAR model [J], economic fabric is 2013.4

[10] liu's win, on the impact of the international oil price fluctuations on China's price level research [D], dissertation, hunan university, 2010 